\title{
TRATABILIDADE DE SOLOS TROPICAIS CONTAMINADOS POR RESÍDUOS DA INDÚSTRIA DE REVESTIMENTOS CERÂMICOS
}

\section{TREATABILITY OF TROPICAL SOILS CONTAMINATED BY SOLID WASTES FROM CERAMIC TILE INDUSTRY}

\begin{abstract}
Luciana Pena DE Oliveira
Tecnóloga em Saneamento pela UNICAMP. Mestre em Engenharia Hidráulica e Sanitária pela Escola Politécnica da Universidade de São Paulo (EPUSP). Consultora em Saneamento Ambiental da Eco-Enob Soluçôes Ambientais Ltda. e do WWF-Brasil

\section{DIONE MARI MORITA}

Engenheira Civil pela Universidade Presbiteriana Mackenzie. Doutora em Engenharia Hidráulica e Sanitária pela EPUSP. Professora Doutora do Departamento de Engenharia Hidráulica e Sanitária da EPUSP
\end{abstract}

Recebido: 29/03/07 Aceito: 18/02/08

\section{RESUMO}

Este trabalho de pesquisa buscou investigar a eficácia da remoção de chumbo $(\mathrm{Pb})$ e zinco $(\mathrm{Zn})$ de uma área contaminada pelo depósito inadequado de resíduos de indústrias de revestimentos cerâmicos do pólo de Santa Gertrudes (São Paulo, Brasil), ocorrido há cerca de trinta anos atrás. Foram avaliados três processos de lixiviação: lavagem com ácido sulfúrico concentrado e por soluçōes de peróxido de hidrogênio a $30 \%$ e de ácido clorídrico $0,1 \mathrm{M}$. Os resultados obtidos mostraram que o tratamento com peróxido de hidrogênio não removeu $\mathrm{Pb}$ e $\mathrm{Zn}$; que a lavagem com ácido sulfúrico concentrado promoveu a redução de $50 \%$ dos teores de $Z n$ e a soluçáo de ácido clorídrico $0,1 \mathrm{M}$ reduziu os teores de $\mathrm{Pb}$ e $\mathrm{Zn}$ em 15\% e 10\%, respectivamente. $\mathrm{O}$ teor remanescente de $\mathrm{Zn}$ no solo tratado com ácido sulfúrico concentrado foi de $117 \mathrm{mg} / \mathrm{kg}$ e os de $\mathrm{Pb}$ e $\mathrm{Zn}$ no solo lavado com a solução de ácido clorídrico $0,1 \mathrm{M}$, de $806 \mathrm{mg} / \mathrm{kg}$ e $213 \mathrm{mg} / \mathrm{kg}$, respectivamente, valores estes inferiores aos de intervenção estabelecidos pelo órgão de controle ambiental paulista.

PALAVRAS-CHAVE: Solo contaminado; metais pesados; remediação, indústria de revestimentos cerâmicos.

\begin{abstract}
The aim of this research was to evaluate different leaching processes to the removal of lead $(P b)$ and zinc $(\mathrm{Zn})$ from tropical soil contaminated by inappropriate past deposition of wastes from ceramic tile industries of Santa Gertrudes (São Paulo, Brazil). Three soil washing processes were investigated: with concentrated sulphuric acid, with a 30\% solution of hydrogen peroxide and with $0.1 M$ solution of hydrochloric acid. The results indicated that the treatment with hydrogen peroxide did not remove $\mathrm{Pb}$ and $Z n$ significantly; the washing with concentrated sulphuric acid caused a $50 \%$ reduction of $Z n$ contents and the $0.1 M$ solution of hydrochloric acid reduced $\mathrm{Pb}$ and $\mathrm{Zn}$ contents in $15 \%$ and $10 \%$, respectively. The $Z n$ content remaining in the soil processed with concentrated sulphuric acid was $117 \mathrm{mg} / \mathrm{kg}$ and the $\mathrm{Pb}$ and $Z n$ contents remaining in the soil processed with $0.1 \mathrm{M}$ solution of hydrochloric acid were $806 \mathrm{mgPb} / \mathrm{kg}$ and 213 $m g Z n / k g$, respectively, values which are lower than intervention ones established by São Paulo State environmental protection agency.
\end{abstract}

KEYWORDS: Contaminated site; tropical soil; heavy metals; remediation; ceramic tile industry.

\section{INTRODUÇÃO}

$\mathrm{O}$ intenso processo de industrialização que transformou o mundo, a disposição inadequada dos resíduos e a exploração não sustentável dos recursos naturais no passado legaram à humanidade um conjunto de passivos ambientais, entre eles, as áreas contaminadas, cujas conseqüências estão sendo sentidas pela presente geração e se nada for feito, seus efeitos perpetuarão para as geraçōes futuras.

Segundo estudo da EPA, realizado em 2004, nos Estados Unidos, 77.000 áreas foram consideradas contaminadas e estima-se que este número será de 294.000 em 2033. O custo estimado para descontaminação de tais áreas varia de 170 a 250 bilhões de dólares. Dos doze poluentes mais freqüentemente detectados nas áreas contaminadas norte-americanas, mais da metade são metais, especialmente o arsênio, o cromo, o chumbo, o zinco, o níquel e o cádmio (USEPA, 2004).

Nos países membros da União Européia, existem 240.000 áreas contaminadas e este número deverá ser $50 \%$ maior em 2025. Cerca de 80.000 sítios já foram remediados. Os poluentes mais freqüentes são: os metais pesados, os óleos minerais e os hidrocarbonetos aromáticos polinucleares (EEA, 2006).

Um diagnóstico do Ministério da Saúde Brasileiro identificou a existência de 703 áreas potenciais e efetivas com populações expostas ou sob risco de exposição a solos contaminados (Brasil, 2006). No Estado de São Paulo, a última atualização do inventário de áreas contaminadas aponta a existência de 1.596 sítios, dos quais 564 tinham algum processo de remediação em andamento, 144 possuíam proposta e apenas 29 já haviam concluído a remediação (CETESB, 2005). Dentre os diversos contaminantes encontrados 
nestas áreas, os metais pesados eram os responsáveis, isolados ou não, pela contaminação de aproximadamente 217 sítios. Todavia, a necessidade de estudos mais detalhados sobre 859 das 1.596 áreas contaminadas, que ainda não possuem proposta de remediação, poderá apontar a presença de metais em outros sítios.

As tecnologias de remediação de áreas contaminadas por metais podem ser agrupadas em biológicas, físicoquímicas e térmicas e são aplicáveis na própria área (in situ) ou ex situ, pelo tratamento do solo escavado, sendo estas baseadas na bioacumulação, lixiviação ou dessorção, volatilização, isolamento físico e na imobilização física e química.

A remediação dos solos contaminados por metais pesados através das tecnologias ex situ apresenta elevado custo, entre US\$ 8 e US\$ 12 por habitante nos países industrializados, devido à firme adesão destes elementos às partículas de solo (Wasay, Barrington e Tokunaga, 1998).

Geralmente, as tecnologias in situ são mais econômicas e seguras, pois a escavação do solo não é necessária (Di Palma et al, 2003), no entanto, não podem ser aplicadas em solos de baixa permeabilidade (Nyer et al, 1996; Rulkens, Grotenhuis e Tichý, 1995).

A Região dos Lagos de Santa Gertrudes é uma das áreas contaminadas por metais pesados do Estado de São Paulo. O descarte indevido de resíduos líquidos e sólidos das indústrias de revestimentos cerâmicos, há mais de 30 anos atrás, proporcionou a contaminação do solo e do lençol freático da bacia do Córrego da Fazenda Itaqui, sub-afluente do Rio Corumbataí, manancial responsável pelo abastecimento de sete municípios do interior paulista e de mais de 650 mil habitantes.

A presente pesquisa buscou estudar a eficácia da remoção dos metais $\mathrm{Pb}$ e $\mathrm{Zn}$ do solo coletado na Região dos Lagos de Santa Gertrudes, por meio da lavagem do solo com ácidos sulfúrico e clorídrico e peróxido de hidrogênio.

\section{MATERIAL E MÉTODOS}

\section{Coleta e preparo das amostras:}

A Região dos "Lagos de Santa Gertrudes" situa-se na porção mais à montante da bacia hidrográfica do
Córrego da Fazenda Itaqui e possui aproximadamente 144 ha. Para fins didáticos, ela foi dividida em três áreas, em função do teor de metais no solo. A área objeto do presente estudo, denominada "Área II", é mostrada na Figura 1. Amostras de solo coletadas em três pontos aleatórios desta área, com trado manual, ao longo do perfil do solo, indicaram baixos teores de metais. Desta forma, optou-se por utilizar o material de desassoreamento das nascentes, que estava disposto em uma pilha, visto que as mesmas estão situadas na base do talude da área II e como o transporte dos contaminantes alvo ocorreu pela ação do escoamento superficial no terreno, um maior teor destes encontrava-se na parte baixa em relação às cotas mais elevadas. Foram coletadas amostras aleatórias, diretamente na pilha, até atingir uma tonelada. Esta foi quarteada e a amostra composta foi transportada e acondicionada em reservatório de polietileno até sua utilização.

As amostras do solo bruto e tratado e do lixiviado utilizadas/geradas durante os ensaios de lavagem com ácido clorídrico concentrado e solução de peróxido de hidrogênio a 30\% seguiram a sistemática descrita a seguir, quanto à sua coleta e preparo, antes de serem enviadas para análise:

a) Solo bruto: toda amostra de solo bruto utilizado nos experimentos foi destorroada e peneirada em malha de $2 \mathrm{~mm}$ para a remoção do material grosseiro. O material resultante foi homogeneizado e procedeu-se a coleta de amostras após o seu quarteamento. Das amostras coletadas, determinou-se a umidade, a fim de permitir a expressão dos resultados das análises químicas em relação ao solo seco a $103 \pm 2{ }^{\circ} \mathrm{C}$ e de determinar o teor de sólidos utilizado no experimento;

b) Solo tratado: o solo tratado (sob a forma de lama) foi coletado em diversas profundidades dos reatores. Em todas as coletas foi controlado o volume e a massa da amostra de lama, a qual recebeu o seguinte tratamento:

- centrifugação por 15 minutos a $4.000 \mathrm{rpm}$, em temperatura ambiente: o objetivo da centrifugação foi o de promover a separação das fases sólida e líquida da amostra;

- fração líquida: após a centrifugação, procedeu-se a coleta do sobrenadante dos tubos de centrífuga e determinou-se seu volume e massa. A amostra líquida foi filtrada em membra- na de $0,45 \mu \mathrm{m}$ de porosidade, recebeu $2 \% \mathrm{v} / \mathrm{v}$ de $\mathrm{HNO}_{3}$ concentrado para sua preservação e foi mantida sob refrigeração a $4^{\circ} \mathrm{C}$ até ser analisada;

- fração sólida: após a remoção do sobrenadante, a fração sólida foi removida dos tubos de centrífuga com espátula metálica e procedeu-se a determinação de sua massa úmida e seca. $\mathrm{Na}$ determinação da massa, utilizou-se cápsula de porcelana, que foi seca em estufa a $60^{\circ} \mathrm{C}$ por 24 horas. Após a determinação da massa seca, a amostra foi triturada em almofariz e acondicionada em saco plástico tipo zip lock até o momento da análise.

A coleta da fase líquida (lixiviado) no ensaio realizado com a solução de ácido clorídrico $0,1 \mathrm{M}$ foi realizada com pipeta graduada de $5 \mathrm{~mL}$, posteriormente filtrada em membrana de $0,45 \mu \mathrm{m}$ de porosidade e mantida sob refrigeração a $4^{\circ} \mathrm{C}$ até a realização da análise química para determinação das concentrações de metais.

\section{Caracterização granulométrica e mineralógica}

A caracterização granulométrica da amostra de solo foi realizada através do procedimento descrito na Norma Técnica 7.181 (Brasil, 1984). A caracterização mineralógica foi realizada através da utilização dos ensaios de difratometria e fluorescência de raios-X.

\section{Determinação da concentração de carbono total, hidrogênio e nitrogênio}

A determinação dos teores de C, $\mathrm{H}$ e $\mathrm{N}$ presentes no solo bruto e na fase sólida da suspensão foi realizada em equipamento Elemental Analyzer 2.400 CHN da Perkin Elmer.

\section{Determinação dos teores de metais pesados}

Os teores e concentrações dos metais $\mathrm{Pb}$ e $\mathrm{Zn}$, presentes no solo bruto e nas fases sólida e líquida da suspensão, foram determinados através da utilização de espectrometria de emissão atômica com plasma de argônio induzido - Método 6010B (USEPA, 1996b). As amostras foram previamente digeridas em solução ácida conforme descrito no Método 3050B (USEPA, 1996a). 


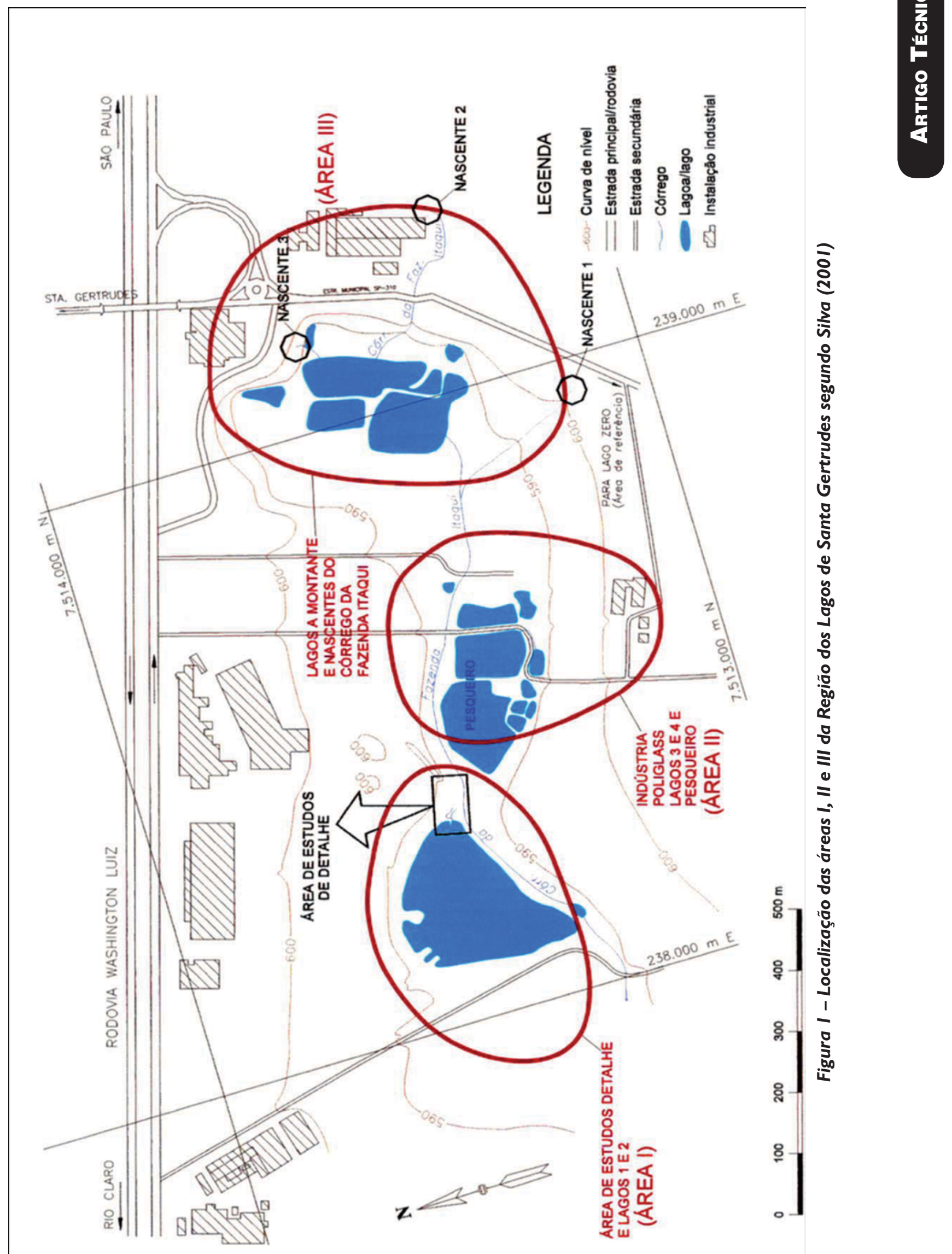




\section{Ensaios de lixiviação}

Os ensaios de lixiviação dos metais $\mathrm{Pb}$ e $\mathrm{Zn}$ do solo com a utilização de ácido sulfúrico concentrado e peróxido de hidrogênio a $30 \%$ foram conduzidos no equipamento representado esquematicamente na Figura 2.

Foi preparada suspensão da amostra de solo coletada na área II, com $25 \%$ de teor de sólidos, mantida sob agitação em $200 \mathrm{rpm}$ e à temperatura ambiente. Os ensaios foram realizados em triplicata.

a) Ensaio com ácido sulfúrico concentrado:

À suspensão de solo, foi adicionado o volume de ácido sulfúrico concentrado necessário à estabilização do pH entre 7 e 2, partindo-se de 8. Após estabilização em cada valor de $\mathrm{pH}$, que levou cerca de 24 horas, amostras de $50 \mathrm{~mL}$ foram coletadas e centrifugadas a $4.000 \mathrm{rpm}$ durante 15 minutos, para separação das fases sólida e líquida. Esta, contendo os metais lixiviados do solo, foi filtrada em membrana Millipore de teflon hidrofílico com porosidade de $0,45 \mu \mathrm{m}$, para separação dos sólidos em suspensão, armazenada acidificada e sob refrigeração. A fase sólida foi seca em estufa a $60^{\circ} \mathrm{C}$ por 24 horas, cuidadosamente masserada e assim como para a fase líquida, foram determinados os teores dos metais $\mathrm{Pb}$ e $\mathrm{Zn}$.

b) Ensaio com solução de peróxido de hidrogênio a 30\%:

A utilização da solução de peróxido de hidrogênio a $30 \%$ objetivou a oxidação dos compostos orgânicos presentes no solo e conseqüente remoção dos metais $\mathrm{Pb}$ e $\mathrm{Zn}$ da matriz sólida. Ao volume de 4 litros de suspensão de solo com teor de sólidos de $25 \%$, foi adicionado volume de peróxido de hidrogênio a 30\% para oxidação do carbono.

$\mathrm{Na}$ Tabela 1 são listadas as dosagens de peróxido de hidrogênio a $30 \%$ utilizadas na investigação experimental.

Após a dosagem do agente oxidante, a suspensão foi mantida sob agitação durante 3 horas. As amostras foram manipuladas e acondicionadas da mesma forma como no ensaio com o ácido sulfúrico.

c) Ensaio com ácido clorídrico $0,1 \mathrm{M}$ :

O procedimento do ensaio com a solução de ácido clorídrico $0,1 \mathrm{M}$ seguiu a etapa de abertura leve da extração seqüencial de metais pesados proposto

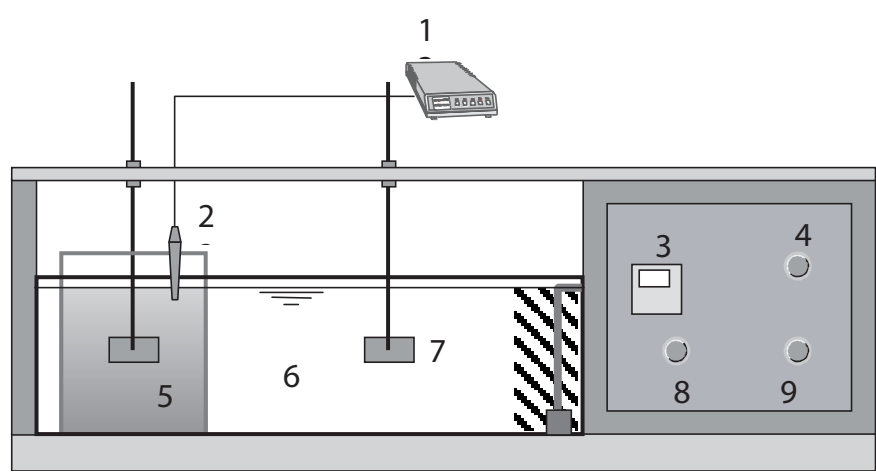

Legenda:

(1) potenciômetro; (2) eletrodo para suspensôes; (3) controle de temperatura;

(4) controle da rotação; (5) reator de $5 \mathrm{~L}$ (capacidade para 4 unidades);

(6) banho termostático; (7) paleta para mistura; (8) controle do sistema de aquecimento; (9) controle do sistema de resfriamento.

Figura 2 - Equipamento utilizado nos ensaios de lixiviação com ácido sulfúrico e peróxido de hidrogênio

Tabela I - Teores de carbono do solo bruto e dosagens de $\mathrm{H}_{2} \mathrm{O}_{2}$ a 30\% utilizadas no ensaio de oxidação do solo contaminado

\begin{tabular}{ccc}
\hline Teor de $\mathrm{C}(\%)$ & $\begin{array}{c}\text { Volume dosado de } \mathrm{H}_{2} \mathrm{O}_{2} \text { a } \\
30 \%(\mathrm{~mL})\end{array}$ & $\begin{array}{c}\text { Massa de } \mathrm{H}_{2} \mathrm{O}_{2} \\
\text { por massa de solo }(\mathrm{g} / \mathrm{kg})(2)\end{array}$ \\
\hline 0,40 & 117 & 151,11 \\
0,61 & 178 & 230,44 \\
0,80 & 234 & 302,22 \\
1,76 & $386(1)$ & 664,88 \\
3,53 & $774(1)$ & $1.333,55$ \\
4,41 & $967(1)$ & $1.666,09$ \\
\hline
\end{tabular}

Obs:

(1) volume da suspensão $=3 \mathrm{~L}$;

(2) massa de $\mathrm{H}_{2} \mathrm{O}_{2}$ por massa de solo $(\mathrm{g} / \mathrm{kg})$ : $\left\{\left[\right.\right.$ (volume de $\mathrm{H}_{2} \mathrm{O}_{2} 30 \%$ dosado (L) $\mathrm{x}$

densidade da solução de $\left.\mathrm{H}_{2} \mathrm{O}_{2} 30 \%(1,11 \mathrm{~kg} / \mathrm{L})\right] /$ massa de solo $\left.(\mathrm{kg})\right\}$ x 100

por Bevilacqua e Lichtig (2004) e Kersten e Förstner (1990). Quantidade superior a $1,2500 \mathrm{~g}$ de amostra de solo foi seca à temperatura de $60^{\circ} \mathrm{C}$ por um período de 96 horas e, na sequiência, transferiu-se uma massa exata de $1,2500 \mathrm{~g}$ a um erlenmeyer de $250 \mathrm{~mL}$. Adicionou-se $25 \mathrm{~mL}$ de $\mathrm{HCl} 0,1 \mathrm{M} \mathrm{e}$ agitou-se essa suspensão em rotação de $200 \mathrm{rpm}$ por período de 2 horas. A suspensão foi mantida em repouso e em seguida filtrada em membrana Millipore de teflon hidrofílico com porosidade de $0,45 \mu \mathrm{m}$, para separação dos sólidos em suspensão. O filtrado foi mantido a $4^{\circ} \mathrm{C}$ até a determinação das concentrações dos metais.

\section{RESULTADOS E DISCUSSÃO}

\section{Caracterização do solo contaminado da área II da região dos lagos de Santa Gertrudes:}

A amostra composta de solo contaminado apresentou $945 \mathrm{mgPb} / \mathrm{kg}$ e $236 \mathrm{mgZn} / \mathrm{kg}$. A caracterização granulométrica do material contaminado identificou a predominante presença de argila, conforme mostra a tabela a seguir. A massa específica foi determinada em $2,7 \mathrm{~g} / \mathrm{cm}^{3}$. 
Tabela 2 - Distribuição Granulométrica da Amostra do Solo Contaminado

\begin{tabular}{ccc}
\hline Fração & Diâmetro das partículas $(\mathrm{mm})$ & Distribuição $(\%)$ \\
\hline Argila & $<0,002$ & 53 \\
Silte & $>0,002$ até 0,05 & 31 \\
Areia fina & $>0,05$ até 0,40 & 15 \\
Areia média & $>0,40$ até 2,00 & 1 \\
\hline
\end{tabular}

A caracterização mineralógica indicou a presença de quartzo, muscovita, ortoclásio, anatásio e caulinita no solo contaminado.

Conforme apresentado no estudo realizado por Silva (2001), os solos no município de Santa Gertrudes foram identificados pelo Instituto Agronômico de Campinas, em 1999, como solos podzólicos e terras roxas estruturadas, ou seja, perfis naturais (horizontes B) de latossolos.

A presença de quartzo é muito freqüente nestes solos, quase sempre predominante nas frações areia e pedregulho (Nogami, 1995).

O quartzo, a muscovita (mica) e o ortoclásio (feldspato), entre outros, são considerados minerais primários, ou seja, aqueles em que a estrutura e a composição química foram obtidas durante o processo de cristalização da lava vulcânica (Evangelou, 1998).

Também podem ocorrer outros minerais resistentes à ação das intempéries (minerais secundários), como aqueles designados genericamente de minerais pesados, dos quais são encontrados com maior freqüência os seguintes: magnetita, ilmenita, rutilo, turmalina, zircão, etc. $\mathrm{O}$ anatásio, geralmente, encontra-se associado ao rutilo e à hematita.

Outro mineral, a rigor, uma associação de minerais, que freqüentemente ocorre nos latossolos, sobretudo na fração pedregulho, é a laterita ou concreção laterítica, constituída essencialmente de óxidos hidratados de ferro e alumínio. A essa substância, associam-se freqüentemente a magnetita, a ilmenita, a hematita e, sobretudo, o quartzo.

Similarmente ao caso da fração areia, a constituição mineralógica da fração silte é quase sempre muito simples, sendo nítida a predominância do quartzo. É bastante freqüente a presença de torrōes de argila e a laterita também pode ocorrer nessa fração, contudo é difícil sua distinção dos primeiros.

Os principais constituintes da fração argila, ou seja, da parte formada por grãos de diâmetro inferior a 0,002 mm são classificados em constituintes minerais (argilo-minerais, óxidos e hidróxidos de ferro e/ou alumínio) e constituintes orgânicos (húmus ou ácidos húmicos).

A fração argila dos latossolos caracteriza-se por conter elevada porcentagem de óxidos e hidróxidos de ferro e alumínio. $\mathrm{O}$ argilo-mineral, geralmente presente na fração argila dos latossolos, é a caulinita.

Os argilo-minerais caracterizam-se por possuir uma série de propriedades peculiares, das quais destacam-se (Nogami, 1995):

- enorme área específica, decorrente sobretudo de suas dimensões diminutas (da ordem de micrômetros a nanômetros) e de sua forma lamelar e/ou alongada;

- cargas elétricas predominantemente negativas, que lhes proporcionam capacidade de troca catiônica, quando em meio aquoso e, também, condicionam o grau de acidez ou $\mathrm{pH}$ do solo;

- adsorção de cátions devido à elevada área superficial específica e predominância da cargas elétricas negativas na superfície de suas partículas.

A análise química semi-quantitativa por fluorescência de raios X mostrou uma predominância de silício, alumínio e ferro.

A predominância de silício deve-se ao fato de que todos os argilo-minerais e a maioria dos minerais formadores de rochas e solos possuem silício em sua composição. A presença de aproximadamente $17 \%$ de alumínio deve-se aos argilo-minerais, sendo a caulinita um silicato aluminoso.

O material contaminado apresenta elevado teor de ferro em sua compo- sição $(8,31 \%)$, tendo sido detectada a hematita na difratometria de raios-X, uma das principais fontes deste elemento, juntamente com a magnetita, limonita, ilmenita, siderita e pirita. A limonita é uma mistura de vários hidróxidos de ferro, incluindo a goetita, lepidocrocita e hidrolepidocrocita, além de impurezas como a matéria argilosa e o quartzo. Por ser amorfo, não é passível de detecção nos ensaios de difratometria de raios-X.

\section{Ensaios de lixiviação:}

a) Ensaio com ácido sulfúrico concentrado:

Os teores de $\mathrm{Pb}$ detectados nos valores de $\mathrm{pH}$ entre 8 e 2 não evidenciam a transferência desse elemento da matriz sólida para a fase líquida, sendo que em $\mathrm{pH}$ inferior a 6 , houve tendência de acréscimo deste teor. $\mathrm{O}$ elevado desvio padrão dos resultados das amostras em valores de $\mathrm{pH}$ de 6,0 e 4,0 pode ser incumbido à heterogeneidade do material estudado (Figura 3).

A suspensão de solo estudada neste trabalho de pesquisa foi mantida durante o ensaio sob condições aeróbias, confirmada visualmente pela coloração vermelho-marrom, típica de solos com elevadas concentraçôes de ferro e de ambientes oxidados, sendo o potencial redox (Eh) estimado na faixa de +400 a +600 mV, conforme Alloway (1995).

Com a adição do ácido sulfúrico à suspensão, provavelmente, ocorreu a formação da espécie $\mathrm{PbSO}_{4}$, que possui baixa solubilidade em água e foi precipitada ${ }^{1}$. Segundo Fuller (1983) apud Bourg (1995), o Cu e o Pb são os metais menos móveis e os mais dificilmente extraídos de uma matriz sólida. Os argilominerais, componentes dos latossolos, possuem partículas com elevada área específica e de permanente carga elétrica negativa (Alloway, 1995), que proporcionam condiçôes ideais à adsorção dos cátions metálicos. As interações entre os metais pesados e os colóides dos solos (argila, substâncias húmicas ou a combinação de ambas) são devidas à troca iônica, adsorção na superfície dos colóides e reações de quelação, sendo que a retenção dos metais pesados, proporcionada por estes colóides, varia com a força iônica, $\mathrm{pH}$, características dos argilominerais, grupos funcionais e cátions competidores (Evangelou, 1998). 
Segundo (Brookins, 1988), em valores de $\mathrm{pH}$ inferiores a $5 \mathrm{e}$ em ambientes oxidados, o sulfato de chumbo é a espécie química predominante e em valores superiores a 5 , mantidas as condiçóes oxidantes do meio, prevalece a presença das espécies que permanecem adsorvidas e complexadas às partículas do solo e dos sedimentos, como o carbonato e os óxidos de chumbo.

Pelos experimentos de extração seqüencial realizados por Silva (2001), verificou-se que a maior parte do chumbo detectado nas amostras de solo coletadas em duas áreas da Região dos Lagos de Santa Gertrudes estava aderida aos óxidos e hidróxidos (entre 32,6 e $55 \%$ ) e à matéria orgânica (entre 28,6 e 41,3\%). O elemento também ocorreu associado aos carbonatos quando em meio alcalino (até 33,7\%). As fraçóes trocáveis e fracamente ligadas foram pouco expressivas.

Para o elemento $\mathrm{Zn}$, foi detectada a tendência de redução dos teores na fase sólida, à medida que a suspensão foi acidificada (Figura 4). Provavelmente, a adição do ácido sulfúrico produziu a formação da espécie solúvel sulfato de zinco $\left(\mathrm{ZnSO}_{4}\right)$ e liberação dos íons $\mathrm{Zn}^{2+}$.

Dessa forma, o elemento zinco, presente em $\mathrm{pH} 8$ e no ambiente oxidado, na forma de hidróxidos $\left(\mathrm{Zn}(\mathrm{OH})_{2}\right)$, carbonatos $\left(\mathrm{ZnCO}_{3}\right)$ e óxidos $(\mathrm{ZnO}$ e $\mathrm{ZnO}_{2}$ ), foi lixiviado da matriz sólida. Como observado para o elemento chumbo, os experimentos de extração seqüencial realizados por Silva (2001) identificaram que a maior parte do zinco detectado nas amostras de solo coletadas em duas áreas da Região do Lago de Santa Gertrudes estava aderida aos óxidos e hidróxidos (entre 36,5 e $55 \%$ ) e à matéria orgânica (entre 28,4 e $50,1 \%)$. A fração associada aos carbonatos foi identificada entre 5,4 e $24,9 \%$ e as fraçôes trocáveis e fracamente ligadas entre 0 e $1,4 \%$ e 1,8 e $6,4 \%$, respectivamente. $\mathrm{O}$ zinco, em geral, apresenta mobilidade relativa mais alta do que a do chumbo (Silva, 2001).

$\mathrm{Na}$ fase líquida da suspensão, foi detectada a tendência do acréscimo da concentração de $\mathrm{Pb}$, sendo que no $\mathrm{pH}$ igual a 4 foi detectada a maior concentração (Figura 5). Isto pode ser explicado pela redução da solubilidade do ácido húmico em $\mathrm{pH}$ inferior a 4,0 e precipitação deste com o chumbo complexado ao mesmo (Jensen, Ottosen e Pedersen, 2006). Esse acrésci- mo não acompanhou aquele observado para as amostras da fase sólida, nas quais o chumbo, provavelmente precipitado na forma de sulfato de chumbo, produziu o acréscimo dos teores inicialmente identificados na suspensão não acidificada.

Houve o acréscimo aproximado de $21 \%$ da massa de chumbo na fase sólida da amostra da suspensão em $\mathrm{pH}$ igual a 2,0 em relação ao detectado na suspensão sem acidificação, sendo esse acréscimo, provavelmente, produzido pela precipitação das espécies inicialmente dissolvidas na suspensão (Tabela 3).

A pequena remoção de $\mathrm{Pb}$ do solo bruto, pós-tratamento com ácido sulfúrico concentrado, obtida através de balanço de massa, deve-se à predomi- nância das formas de chumbo precipitadas e adsorvidas às partículas do solo. A maior remoção $(3,7 \%)$ ocorreu em $\mathrm{pH}$ igual a 4 , sendo o teor remanescente no solo tratado de $910 \mathrm{mg} / \mathrm{kg}$.

A lixiviação do $\mathrm{Zn}$ mostrou-se eficiente com o decréscimo do $\mathrm{pH}$ (Figura 6), o que coincide com a redução dos teores detectados nas amostras da fase sólida. A acidificação de um meio oxidado favorece a presença dos íons $\mathrm{Zn}^{2+}$, que são espécies solúveis (Brookins, 1988).

$\mathrm{Na}$ fase líquida da suspensão, foi detectada a dessorção de $\mathrm{Zn}$ da matriz sólida a partir do $\mathrm{pH} 6$. Houve a redução de aproximadamente $32 \%$ da massa de zinco na fase sólida da suspensão em pH igual a 2 em relação ao detectado na suspensão sem acidificação (Tabela 4).

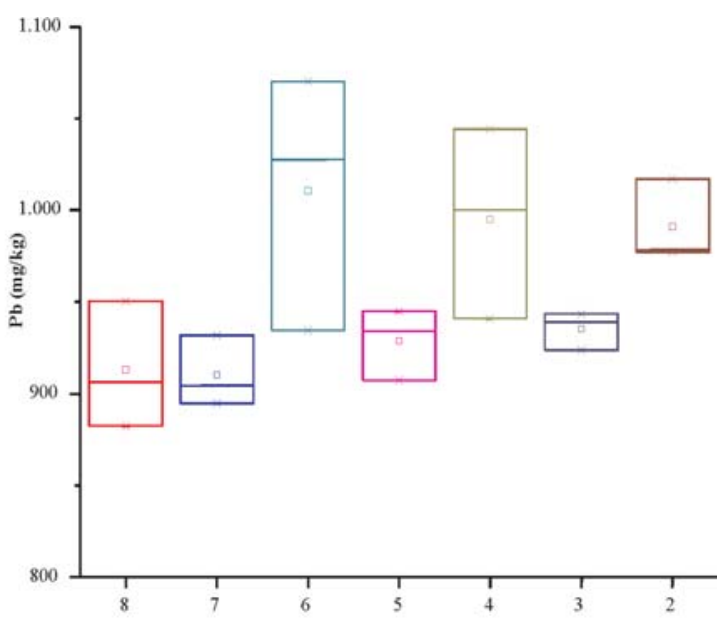

Figura 3 - Teores mínimos, médios e máximos de $\mathrm{Pb}$ detectados na fase sólida da suspensão no ensaio com ácido sulfúrico

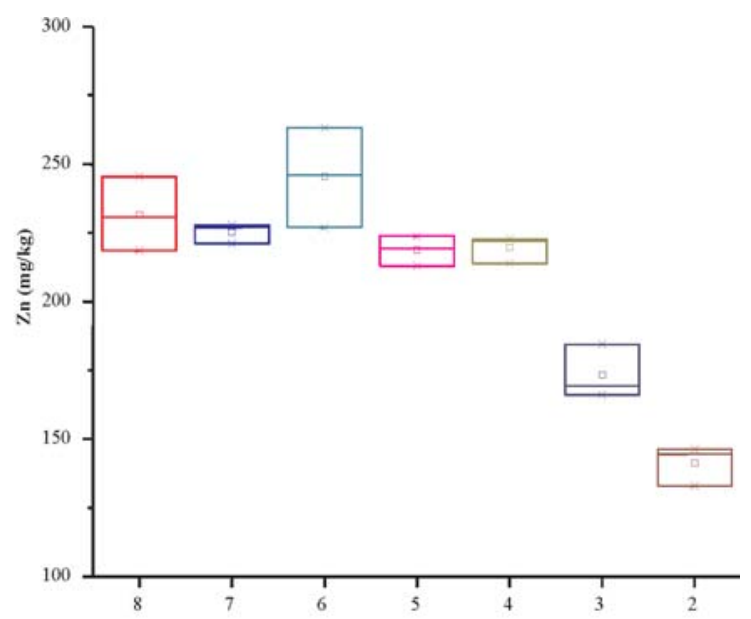

$\mathrm{pH}$

Figura 4 - Teores mínimos, médios e máximos de Zn detectados na fase sólida da suspensão no ensaio com ácido sulfúrico 


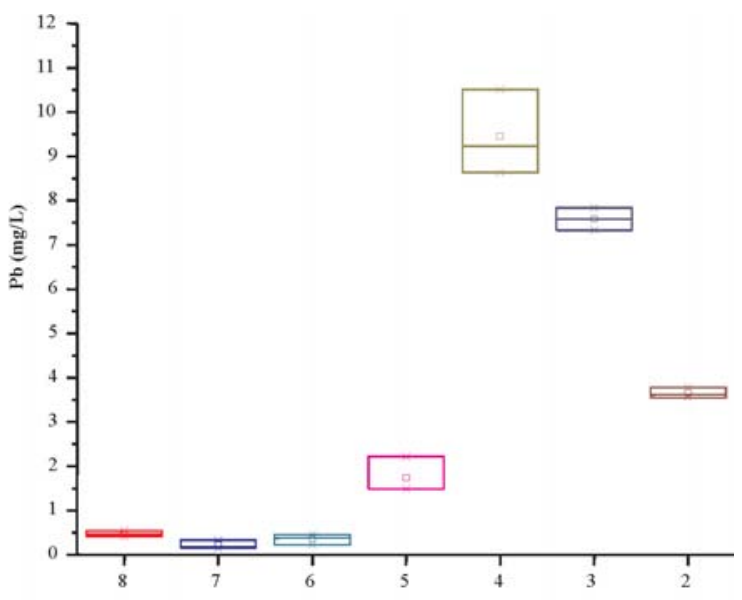

$\mathrm{pH}$

Figura 5 - Concentrações mínimas, médias e máximas de $\mathrm{Pb}$ detectadas na fase líquida da suspensão no ensaio com ácido sulfúrico

Tabela 3 - Massa de Pb nas suspensões sem acidificação e tratadas com ácido sulfúrico concentrado

\begin{tabular}{|c|c|c|c|c|c|}
\hline $\mathrm{pH}$ & $\begin{array}{l}\text { Massa de Pb total } \\
\text { na suspensão } \\
(\mathrm{mg})^{(1)}\end{array}$ & $\begin{array}{l}\text { Massa de Pb na fase } \\
\text { sólida da suspensão } \\
\qquad(\mathrm{mg})^{(2)}\end{array}$ & $\begin{array}{l}\text { Massa de Pb adsorvido nas } \\
\text { partículas da fase líquida da } \\
\text { suspensão }(\mathrm{mg})^{(3)}\end{array}$ & $\begin{array}{l}\text { Massa de Pb dissolvido na } \\
\text { fase líquida da suspensão } \\
(\mathrm{mg})^{(4)}\end{array}$ & $\begin{array}{c}\text { Percentual de } \\
\text { remoção de } \mathrm{Pb} \\
(\%)^{(5)}\end{array}$ \\
\hline 8,0 & 811,33 & 583,88 & 225,95 & 1,50 & 0,18 \\
\hline 7,0 & 811,33 & 600,28 & 210,35 & 0,70 & 0,09 \\
\hline 6,0 & 811,33 & 685,85 & 124,35 & 1,13 & 0,14 \\
\hline 5,0 & 811,33 & 633,38 & 172,51 & 5,44 & 0,67 \\
\hline 4,0 & 811,33 & 687,51 & 94,11 & 29,71 & 3,66 \\
\hline 3,0 & 811,33 & 653,00 & 134,5 & 23,83 & 2,94 \\
\hline 2,0 & 811,33 & 704,61 & 95,25 & 11,47 & 1,41 \\
\hline \multicolumn{6}{|c|}{ 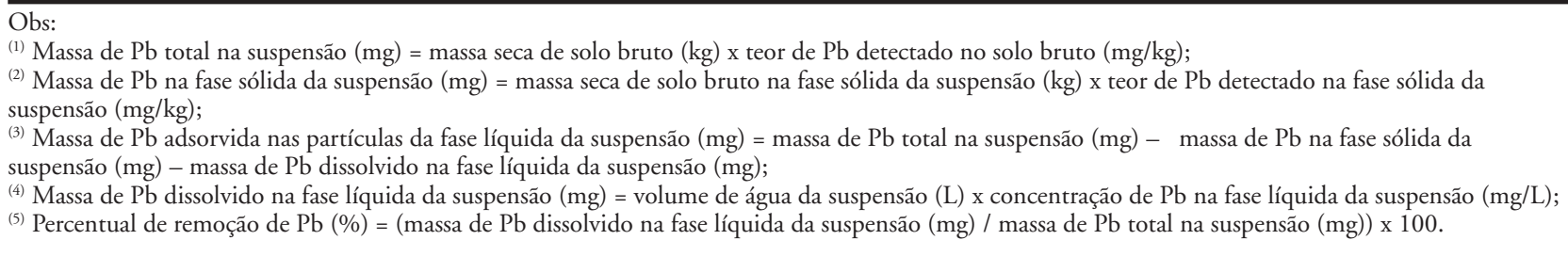 } \\
\hline
\end{tabular}

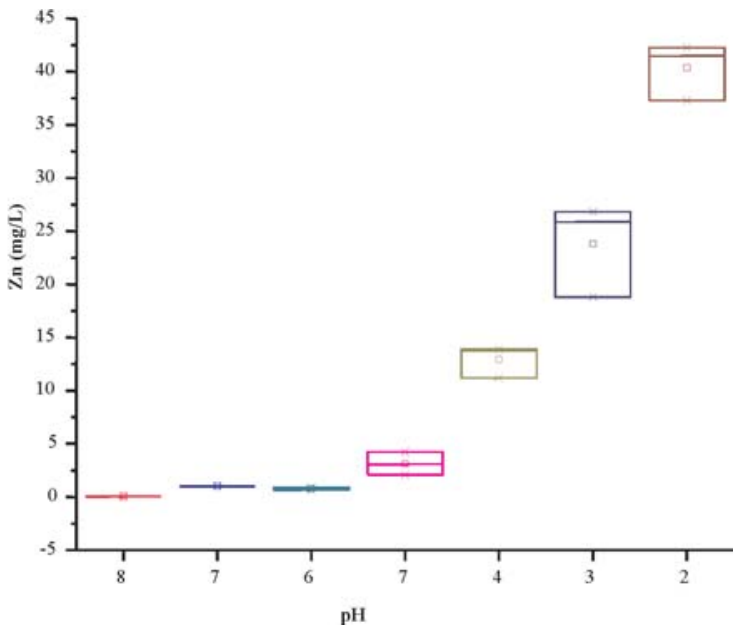

Figura 6 - Concentrações mínimas, médias e máximas de Zn detectadas na fase líquida da suspensão no ensaio com ácido sulfúrico 
A espécie móvel $\mathrm{Zn}^{2+}$ é predominante em ambientes oxidados e em valores de $\mathrm{pH} \leq 7,7$ (Alloway, 1995). A massa de $\mathrm{Zn}$ remanescente na fase sólida da suspensão (solo tratado), obtida através de balanço de massa, está entre 1,2\% ( $\mathrm{pH}$ 6) e 50,4\% ( $\mathrm{pH} \mathrm{2),} \mathrm{inferior} \mathrm{à} \mathrm{de-}$ tectada no solo bruto, sendo os teores remanescentes de 233 e $117 \mathrm{mgZn} / \mathrm{kg}$, respectivamente.

b) Ensaio com solução de peróxido de hidrogênio a 30\%:

Conforme valores médios obtidos nos ensaios e representados na Figura 7 , evidencia-se a redução dos teores de $\mathrm{Pb}$ da matriz sólida após oxidação do sistema e manutençâo dos valores do $\mathrm{pH}$ próximos a 8,0. Observou-se o elevado desvio padrão dos resultados das amostras das dosagens 4,53; 20,00 e 50,00\%, que pode ser devido à heterogeneidade do material estudado.

A oxidação da matéria orgânica do meio objetivou a liberação dos íons metálicos complexados aos compostos húmicos (polieletrólitos de moderado a elevado peso molecular) e não húmicos (aminoácidos, carboidratos, ácidos orgânicos e lipídios) presentes no solo bruto.

O potencial das substâncias húmicas de formar complexos com os metais pesados deve-se à presença do oxigênio nos grupos funcionais como as carboxilas $(\mathrm{COOH})$, hidroxilas $(\mathrm{OH})$ e carbonilas $(\mathrm{C}=\mathrm{O})$. Geralmente, as substâncias húmicas formam um forte complexo com a argila e os mecanismos de formação dos complexos diferem de acordo com as características dos argilominerais e envolvem a ocorrência de complexos de esferas externas (adsorção física) e de esferas internas (quimiossorção), sendo que os primeiros se caracterizam por uma fraca associação eletrostática entre a superfície elétrica do colóide e um cátion hidratado que pode ser facilmente substituído por outro capaz de formar complexos da mesma natureza. Os complexos de esferas internas são relativamente fortes e formados entre o contato da superfície elétrica do colóide com um cátion não hidratado, sendo que este cátion

Tabela 4 - Massa de Zn nas suspensões sem acidificação e tratadas com ácido sulfúrico concentrado

\begin{tabular}{cccccc}
\hline pH & $\begin{array}{c}\text { Massa de } \\
\text { Zn total na } \\
\text { suspensão }(\mathrm{mg})^{(1)}\end{array}$ & $\begin{array}{c}\text { Massa de Zn na fase } \\
\text { sólida da suspensão } \\
(\mathrm{mg})^{(2)}\end{array}$ & $\begin{array}{c}\text { Massa de Zn adsorvido nas } \\
\text { partículas da fase líquida da } \\
\text { suspensão }(\mathrm{mg})^{(3)}\end{array}$ & $\begin{array}{c}\text { Massa de Zn dissolvido na } \\
\text { fase líquida da suspensão } \\
(\mathrm{mg})^{(4)}\end{array}$ & $\begin{array}{c}\text { Percentual de } \\
\text { remoção de Zn } \\
(\%)^{(5)}\end{array}$ \\
\hline 8,0 & 202,73 & 148,01 & 54,72 & não detectada & 0,00 \\
7,0 & 202,73 & 148,53 & 54,2 & não detectada & 0,00 \\
6,0 & 202,73 & 166,52 & 33,8 & 2,41 & 1,19 \\
5,0 & 202,73 & 149,17 & 43,75 & 9,81 & 4,84 \\
4,0 & 202,73 & 151,81 & 10,26 & 40,66 & 20,01 \\
3,0 & 202,73 & 120,99 & 6,89 & 74,85 & 36,92 \\
2,0 & 202,73 & 100,48 & 0,00 & 102,25 & 50,44 \\
\hline
\end{tabular}

Obs:

(1) Massa de $\mathrm{Zn}$ total na suspensão $(\mathrm{mg})$ = massa seca de solo bruto $(\mathrm{kg}) \mathrm{x}$ teor de $\mathrm{Zn}$ detectado no solo bruto (mg/kg);

(2) Massa de Zn na fase sólida da suspensão $(\mathrm{mg})$ = massa seca de solo bruto na fase sólida da suspensão (kg) x teor de Zn detectado na fase sólida da suspensão $(\mathrm{mg} / \mathrm{kg})$;

(3) Massa de Zn adsorvida nas partículas da fase líquida da suspensão $(\mathrm{mg})$ = massa de $\mathrm{Zn}$ total na suspensão (mg) - massa de Zn na fase sólida da suspensão (mg) - massa de Zn dissolvido na fase líquida da suspensão (mg);

(4) Massa de Zn dissolvido na fase líquida da suspensão $(\mathrm{mg})$ = volume de água da suspensão (L) x concentração de Zn na fase líquida da suspensão (mg/L);

(5) Percentual de remoção de $\mathrm{Zn}(\%)=($ massa de $\mathrm{Zn}$ dissolvido na fase líquida da suspensão (mg) / massa de Zn total na suspensão (mg) $\mathrm{x} 100$.

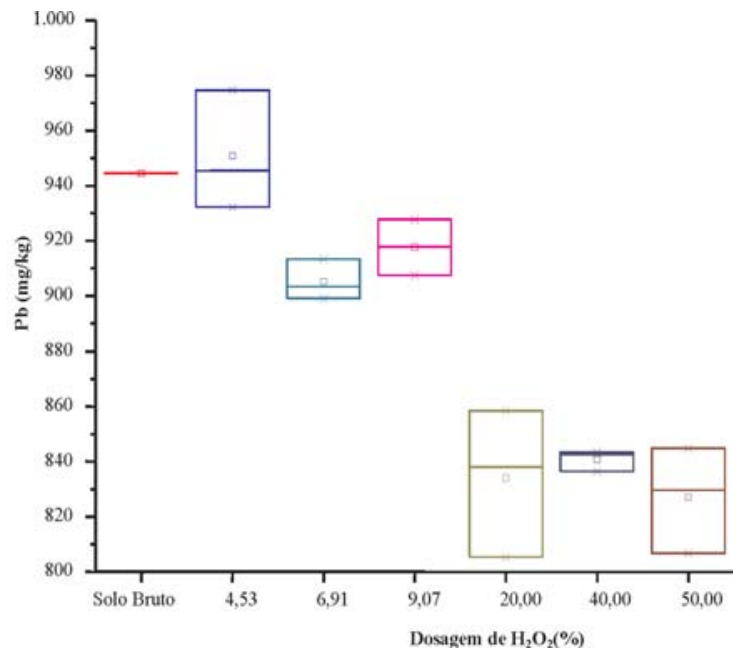

Figura 7 - Teores mínimos, médios e máximos de Pb detectados no solo bruto e na fase sólida da suspensão no ensaio com peróxido de hidrogênio 
somente poderá ser substituído por outro que possa formar um complexo idêntico (Evangelou, 1998).

A análise elementar indicou a presença de carbono total no solo na faixa de 0,4 a $0,8 \%$, sendo o teor de matéria orgânica estimado entre 0,7 a $1,3 \%$, condizente aos teores geralmente encontrados em solos tropicais da América do Sul (Sanchez, 1976 apud Alloway, 1995).

Os complexos coloidais organominerais desempenham uma importan- te função no controle das concentraçôes dos íons nos solos (Alloway, 1995). Harter (1983) apud Evangelou (1998) demonstraram que a adsorção do $\mathrm{Pb}$ aumenta com o aumento do $\mathrm{pH}$ e é maior no horizonte A do que no horizonte $\mathrm{B}$ dos solos, pois, no primeiro, geralmente ocorre maior quantidade de matéria orgânica, que possui elevada densidade de carga elétrica negativa e grande dependência do valor do $\mathrm{pH}$.

Assim como detectado para o elemento chumbo, houve redução da massa de $Z n$ na fase sólida da suspensão (Figura 8).

A redução dos teores de $\mathrm{Pb}$ da fase sólida da suspensão não foi acompanhada do aumento da concentração deste elemento na fase líquida, com o acréscimo da dosagem da solução de peróxido de hidrogênio. Provavelmente, a massa de chumbo lixiviada da fase sólida foi transferida para os sólidos em suspensão, que ficaram retidos na membrana de porosidade 0,45 $\mu \mathrm{m}$, como também, devido à reação

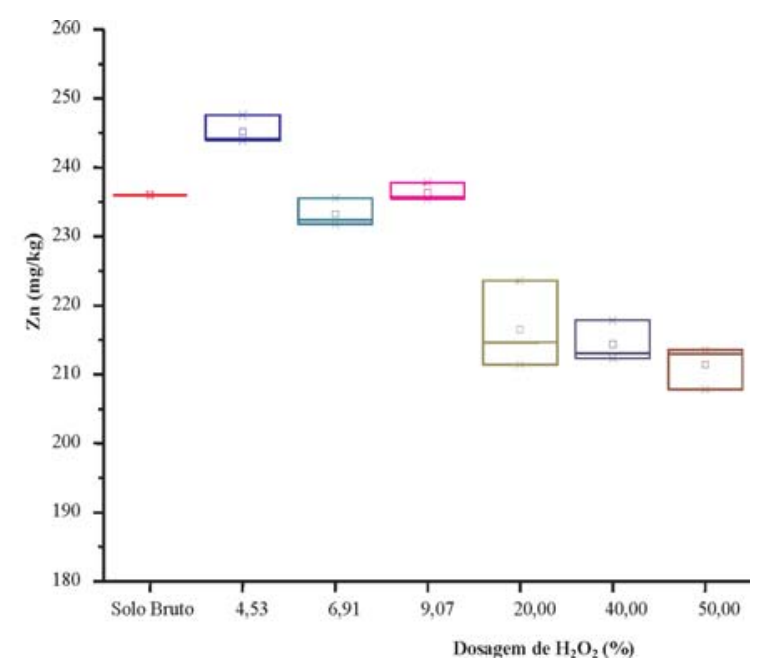

Figura 8 - Teores mínimos, médios e máximos de Zn detectados no solo bruto e na fase sólida da suspensão no ensaio com peróxido de hidrogênio

Tabela 5 - Massa de Pb nas suspensões não oxidada e tratadas com a solução de peróxido de hidrogênio a 30\%

\begin{tabular}{cccccc}
\hline $\begin{array}{c}\text { Dosagem } \\
\mathrm{H}_{2} \mathrm{O}_{2} \\
30 \%(\%)\end{array}$ & $\begin{array}{c}\text { Massa de Pb total } \\
\text { na suspensão } \\
(\mathrm{mg})^{(1)}\end{array}$ & $\begin{array}{c}\text { Massa de Pb na } \\
\text { fase sólida da } \\
\text { suspensão }(\mathrm{mg})^{(2)}\end{array}$ & $\begin{array}{c}\text { Massa de Pb adsorvido nas } \\
\text { partículas da fase líquida } \\
\text { da suspensão }(\mathrm{mg})^{(3)}\end{array}$ & $\begin{array}{c}\text { Massa de Pb dissolvido } \\
\text { na fase líquida da } \\
\text { Suspensão }(\mathrm{mg})^{(4)}\end{array}$ & $\begin{array}{c}\text { Percentual de } \\
\text { remoção de Pb } \\
(\%)^{(5)}\end{array}$ \\
\hline 0,00 & 811,33 & 583,88 & 225,95 & 1,50 & 0,18 \\
4,53 & 811,33 & 574,13 & 237,20 & não detectada & 0,00 \\
6,91 & 811,33 & 562,94 & 247,25 & 1,14 & 0,14 \\
9,07 & 811,33 & 578,50 & 231,79 & 1,04 & 0,13 \\
20,00 & 811,33 & 490,66 & 319,94 & 0,73 & 0,09 \\
40,00 & 811,33 & 446,32 & 364,72 & 0,29 & 0,04 \\
50,00 & 811,33 & 421,44 & 389,69 & 0,20 & 0,02 \\
\hline
\end{tabular}

Obs:

(1) Massa de $\mathrm{Pb}$ total na suspensão $(\mathrm{mg})$ = massa seca de solo bruto $(\mathrm{kg}) \mathrm{x}$ teor de $\mathrm{Pb}$ detectado no solo bruto $(\mathrm{mg} / \mathrm{kg})$;

(2) Massa de Pb na fase sólida da suspensão $(\mathrm{mg})$ = massa seca de solo bruto na fase sólida da suspensão (kg) x teor de Pb detectado na fase sólida da suspensão $(\mathrm{mg} / \mathrm{kg})$;

(3) Massa de $\mathrm{Pb}$ adsorvida nas partículas da fase líquida da suspensão $(\mathrm{mg})$ = massa de $\mathrm{Pb}$ total na suspensão $(\mathrm{mg})-\mathrm{massa}$ de $\mathrm{Pb}$ na fase sólida da suspensão $(\mathrm{mg})$ - massa de $\mathrm{Pb}$ dissolvido na fase líquida da suspensão (mg);

(4) Massa de $\mathrm{Pb}$ dissolvido na fase líquida da suspensão $(\mathrm{mg})$ = volume de água da suspensão (L) x concentração de $\mathrm{Pb}$ na fase líquida da suspensão (mg/L);

(5) Percentual de remoção de $\mathrm{Pb}(\%)=\{[$ massa de $\mathrm{Pb}$ total na suspensão (mg) - massa de $\mathrm{Pb}$ dissolvido na fase líquida da suspensão (mg) $/$ massa de $\mathrm{Pb}$ total na suspensão $(\mathrm{mg})\}$ x 100 . 
altamente exotérmica, desencadeada a partir da adição da solução de peróxido de hidrogênio à suspensão de material contaminado, com ocorrência de grande liberação de vapores e pequena perda de massa, o chumbo dissolvido na fase líquida pode ter sido perdido (Tabela 5).

Como observado para o elemento chumbo, a redução dos teores de $\mathrm{Zn}$ da fase sólida da suspensão não foi acompanhada do aumento da concentração na fase líquida, com o acréscimo da dosagem da solução de peróxido, tendo sido a massa de zinco da fase sólida, transferida para os sólidos em suspensão que ficaram retidos na membrana de porosidade $0,45 \mu \mathrm{m}$ ou reduzida pela perda parcial de massa da suspensão de solo (Tabela 6). $0,1 \mathrm{M}$ :

a) Ensaio com ácido clorídrico

O zinco e o chumbo podem ser encontrados nos solos como cátions divalentes solúveis na fase aquosa, adsorvidos aos óxidos e hidróxidos de ferro e alumínio, ligados à matéria orgânica ou como óxidos insolúveis.

Os resultados indicam que a adição de água no solo natural oca- sionou uma dessorção de chumbo e zinco, atingindo concentraçôes de até $540 \mu \mathrm{gPb} / \mathrm{L}$ e $62 \mu \mathrm{gZn} / \mathrm{L}$ na fase aquosa. Com a adição de solução de $\mathrm{HCl} \mathrm{0,1} \mathrm{M,} \mathrm{estas} \mathrm{concentrações} \mathrm{aumen-}$ taram significativamente, induzindo à conclusão que houve uma solubilização dos metais com a adição do ácido e posteriormente, a formação de cloretos metálicos, que são solúveis em água. Foram observadas remoçôes médias de zinco e chumbo de $9,7 \%$ e $14,6 \%$, respectivamente (Tabelas 7 e 8).

Tabela 6 - Massa de Zn nas suspensões não oxidada e tratadas com a solução de peróxido de hidrogênio a 30\%

\begin{tabular}{|c|c|c|c|c|c|}
\hline $\begin{array}{c}\text { Dosagem } \\
\mathrm{H}_{2} \mathrm{O}_{2} \\
30 \%(\%)\end{array}$ & $\begin{array}{c}\text { Massa de } \\
\text { Zn total na } \\
\text { suspensão }(\mathrm{mg})^{(1)}\end{array}$ & $\begin{array}{l}\text { Massa de } \mathrm{Zn} \text { na } \\
\text { fase sólida da } \\
\text { suspensão }(\mathrm{mg})^{(2)}\end{array}$ & $\begin{array}{l}\text { Massa de } \mathrm{Zn} \text { adsorvido nas } \\
\text { partículas da fase líquida } \\
\text { da suspensão }(\mathrm{mg})^{(3)}\end{array}$ & $\begin{array}{l}\text { Massa de } \mathrm{Zn} \text { dissolvido } \\
\text { na fase líquida da } \\
\text { suspensão }(\mathrm{mg})^{(4)}\end{array}$ & $\begin{array}{l}\text { Percentual de } \\
\text { remoção de } \mathrm{Zn} \\
(\%)^{(5)}\end{array}$ \\
\hline 0,00 & 202,73 & 148,01 & 54,72 & não detectada & 0,00 \\
\hline 4,53 & 202,73 & 148,01 & 54,72 & não detectada & 0,00 \\
\hline 6,91 & 202,73 & 145,06 & 57,43 & 0,24 & 0,12 \\
\hline 9,07 & 202,73 & 148,85 & 53,68 & 0,20 & 0,10 \\
\hline 20,00 & 202,73 & 127,41 & 75,32 & não detectada & 0,00 \\
\hline 40,00 & 202,73 & 113,81 & 88,92 & não detectada & 0,00 \\
\hline 50,00 & 202,73 & 107,73 & 95,00 & não detectada & 0,00 \\
\hline
\end{tabular}

Obs:

(1) Massa de Zn total na suspensão $(\mathrm{mg})$ = massa seca de solo bruto $(\mathrm{kg}) \mathrm{x}$ teor de $\mathrm{Zn}$ detectado no solo bruto (mg/kg);

(2) Massa de $\mathrm{Zn}$ na fase sólida da suspensão $(\mathrm{mg})$ = massa seca de solo bruto na fase sólida da suspensão (kg) x teor de Zn detectado na fase sólida da suspensão $(\mathrm{mg} / \mathrm{kg})$;

(3) Massa de Zn adsorvida nas partículas da fase líquida da suspensão (mg) = massa de Zn total na suspensão (mg) - massa de Zn na fase sólida da suspensão (mg) - massa de Zn dissolvido na fase líquida da suspensão (mg);

(4) Massa de $\mathrm{Zn}$ dissolvido na fase líquida da suspensão $(\mathrm{mg})$ = volume de água da suspensão (L) x concentração de Zn na fase líquida da suspensão $(\mathrm{mg} / \mathrm{L})$;

(5) Percentual de remoção de $\mathrm{Zn}(\%)=\{[$ massa de $\mathrm{Zn}$ total na suspensão $(\mathrm{mg})$ - massa de $\mathrm{Zn}$ dissolvido na fase líquida da suspensão (mg)] / massa de $\mathrm{Zn}$ total na suspensão $(\mathrm{mg})\}$ x 100 .

Tabela 7 - Massa de Zn nas suspensões não acidificada e tratadas com solução de acido calorídrico 0, I M

\begin{tabular}{|c|c|c|c|c|}
\hline Amostra & $\begin{array}{c}\text { Massa de } \mathrm{Zn} \\
\text { total na } \\
\text { suspensão }(\mathrm{mg})^{(1)}\end{array}$ & $\begin{array}{c}\text { Massa de } \mathrm{Zn} \text { dissolvido } \\
\text { na fase líquida da } \\
\text { suspensão }(\mathrm{mg})^{(2)}\end{array}$ & $\begin{array}{c}\text { Massa de } \mathrm{Zn} \text { remanescente } \\
\text { na fase sólida da } \\
\text { suspensão }(\mathrm{mg})^{(3)}\end{array}$ & $\begin{array}{l}\text { Percentual de } \\
\text { remoção de } \\
\operatorname{Zn}(\%)^{(4)}\end{array}$ \\
\hline Não acidificada & 202,73 & Não detectada & 202,73 & 0,00 \\
\hline $\mathrm{HCl}$ - Ensaio 1 & 202,73 & 24,05 & 178,68 & 11,86 \\
\hline $\mathrm{HCl}$ - Ensaio 2 & 202,73 & 18,26 & 184,47 & 9,01 \\
\hline $\mathrm{HCl}$ - Ensaio 3 & 202,73 & 16,65 & 186,08 & 8,21 \\
\hline $\mathrm{HCl}$ - Média dos Ensaios & 202,73 & 19,65 & 183,08 & 9,69 \\
\hline \multicolumn{5}{|c|}{$\begin{array}{l}\text { Obs: } \\
\text { (1) Massa de } \mathrm{Zn} \text { total na suspensão }(\mathrm{mg})=\text { massa seca de solo bruto }(\mathrm{kg}) \text { x teor de } \mathrm{Zn} \text { detectado no solo bruto }(\mathrm{mg} / \mathrm{kg}) \text {; } \\
\text { (2) Massa de } \mathrm{Zn} \text { dissolvido na fase líquida da suspensão }(\mathrm{mg})=\text { volume de água da suspensão }(\mathrm{L}) \text { x concentração de } Z \mathrm{n} \text { na fase líquida da } \\
\text { suspensão }(\mathrm{mg} / \mathrm{L}) \text {; } \\
\text { (3) Massa de } \mathrm{Zn} \text { remanescente na fase sólida da suspensão }(\mathrm{mg})=\text { massa de } \mathrm{Zn} \text { total na suspensão }(\mathrm{mg}) \text { - massa de Zn dissolvido na fase líquida da } \\
\text { suspensão }(\mathrm{mg}) \text {; } \\
\text { (4) Percentual de remoção de } \mathrm{Zn}(\%)=\{[\text { massa de } \mathrm{Zn} \text { total na suspensão }(\mathrm{mg}) \text { - massa de } Z \mathrm{n} \text { remanescente na fase sólida da suspensão (mg) } / \text { massa } \\
\text { de Zn total na suspensão }(\mathrm{mg})\} \text { x } 100\end{array}$} \\
\hline
\end{tabular}


Tabela 8 - Massa de Pb nas suspensões não acidificada e tratadas com solução de ácido clorídrico 0, I M

\begin{tabular}{|c|c|c|c|c|}
\hline Amostra & $\begin{array}{c}\text { Massa de } \mathrm{Pb} \\
\text { total na } \\
\text { suspensão }(\mathrm{mg})^{(1)}\end{array}$ & $\begin{array}{c}\text { Massa de Pb dissolvido } \\
\text { na fase líquida da } \\
\text { suspensão }(\mathrm{mg})^{(2)}\end{array}$ & $\begin{array}{c}\text { Massa de } \mathrm{Pb} \\
\text { remanescente na fase sólida } \\
\text { da Suspensão }(\mathrm{mg})^{(3)}\end{array}$ & $\begin{array}{l}\text { Percentual de } \\
\text { remoção de } \\
\mathrm{Pb}(\%)^{(4)}\end{array}$ \\
\hline Não acidificada & 811,33 & 1,50 & 809,83 & 0,18 \\
\hline $\mathrm{HCl}$ - Ensaio 1 & 811,33 & 133,12 & 678,21 & 16,41 \\
\hline $\mathrm{HCl}$ - Ensaio 2 & 811,33 & 105,42 & 705,91 & 12,99 \\
\hline $\mathrm{HCl}$ - Ensaio 3 & 811,33 & 117,43 & 693,9 & 14,47 \\
\hline $\mathrm{HCl}$ - Média dos Ensaios & 811,33 & 118,66 & 692,67 & 14,62 \\
\hline
\end{tabular}

Obs:

${ }^{(1)}$ Massa de $\mathrm{Pb}$ total na suspensão $(\mathrm{mg})$ = massa seca de solo bruto $(\mathrm{kg})$ x teor de $\mathrm{Pb}$ do solo bruto $(\mathrm{mg} / \mathrm{kg})$;

(2) Massa de $\mathrm{Pb}$ dissolvido na fase líquida da suspensão $(\mathrm{mg})$ = volume de água da suspensão (L) x concentração de Pb na fase líquida da suspensão $(\mathrm{mg} / \mathrm{L})$;

(3) Massa de $\mathrm{Pb}$ remanescente na fase sólida da suspensão $(\mathrm{mg})$ = massa de $\mathrm{Pb}$ total na suspensão $(\mathrm{mg})$ - massa de Pb dissolvido na fase líquida da suspensão $(\mathrm{mg})$;

(4) Percentual de remoção de $\mathrm{Pb}(\%)=\{[$ massa de $\mathrm{Pb}$ total na suspensão $(\mathrm{mg})$ - massa de $\mathrm{Pb}$ remanescente na fase sólida da suspensão (mg) $]$ / massa de $\mathrm{Pb}$ total na suspensão $(\mathrm{mg})\}$ x 100

A solubilização dos metais presentes no solo, com a adição de solução de ácido clorídrico, obtida nesta pesquisa, foi atestada por diversos pesquisadores, sendo citados alguns nos parágrafos a seguir.

Em 1989, a Canadian Council of Ministers of Environment estabeleceu o National Contaminated Sites Remediation Program (NCSRP), que tinha por finalidade obter dados mais consistentes de tecnologias de remediação, a fim de aplicá-las nos locais mais contaminados do Canadá. Dentro deste Programa, foi realizado um estudo piloto em uma área contaminada, localizada em Saint John, New Brunswick (Canadá, 1993). Fluido dielétrico contendo $\mathrm{PCBs}$ e metais pesados $(\mathrm{Cd}$, $\mathrm{Cu}, \mathrm{Pb}$ e $\mathrm{Zn}$ ) contaminaram o solo. A lavagem com ácido clorídrico, em $\mathrm{pH} 2,0$, resultou na redução dos teores de chumbo de $22.800 \mathrm{mg} / \mathrm{kg}$ a $8.420 \mathrm{mg} / \mathrm{kg}(63 \%)$ e de zinco de $4.130 \mathrm{mg} / \mathrm{kg}$ a $2.700 \mathrm{mg} / \mathrm{kg}(35 \%)$, após tempo de contato de 2 horas.

A EPA (USEPA, 1994) realizou um trabalho, cujo objetivo era determinar a eficácia e a viabilidade econômica da lavagem ácida de solos contaminados na redução das concentrações e da lixiviabilidade de metais pesados. Cinco tipos de solo foram testados. Eles continham elevados teores de arsênio, cádmio, cromo, cobre, chumbo, níquel e zinco. Os teores de zinco variaram de 239 a $14.000 \mathrm{mg} / \mathrm{kg}$ e os de chumbo, de 390 a $29.200 \mathrm{mg} / \mathrm{kg}$. Os resultados mostraram que a lavagem ácida era capaz de tratar todos os tipos de solo estudados, obtendo remoções de zinco e chumbo de 18 a $96 \%$ e 34 a $95 \%$, respectivamente, em $\mathrm{pH}$ igual a 2,0. Entretanto, as concentraçóes de chumbo no lixiviado do solo tratado não atendiam aos limites legais.

Segundo Alloway (1995), a efetiva redução dos teores de chumbo de um solo pode ser obtida com a diminuição do $\mathrm{pH}$ para 2,5-3,0, através da adição de soluções de ácido clorídrico ou de cloreto férrico, sendo que a primeira produz a solubilização e a segunda, a precipitação do elemento.

Reed, Carrieri e Moore (1996) investigaram a remediação de um solo arenoso contaminado artificialmente com chumbo, pela lavagem com solução de $\mathrm{HCl}$ 0,1 M, EDTA 0,01 M e cloreto de cálcio $1 \mathrm{M}$, em ensaio de laboratório, em coluna operada continuamente. Obtiveram eficiência de remoção de $85 \%$ de chumbo (teor inicial de 500 a $600 \mathrm{mg} / \mathrm{kg}$ ), mas este tratamento não reduziu as concentraçóes ao nível de background $(25 \mathrm{mg} / \mathrm{kg})$.

As baixas remoçôes dos dois metais, obtidas no presente trabalho, provavelmente, devem-se à utilização de uma solução fraca de ácido clorídrico, com apenas um ciclo de extração, num solo argiloso. Os resultados corroboram com os obtidos por Pichtel e Pichtel (1997), que compararam a lavagem de solo contaminado de uma unidade industrial abandonada, que continha $4.940 \mathrm{mg} / \mathrm{kg}$ de cromo total e $1.300 \mathrm{mg} / \mathrm{kg}$ de chumbo, $\mathrm{pH}$ igual a 10,3 , com soluções de EDTA $(0,1 ; 0,01 ; 0,001$ e $0,0001 \mathrm{M})$, ácido nitriloacético $(0,1$ e $0,001 \mathrm{M})$, dodecil sulfato de sódio $(0,1$ e $0,001 \mathrm{M})$ e ácido clorídrico $(0,25$ a $8 \% \mathrm{v} / \mathrm{v})$. A lavagem com solução de ácido clorídrico a $1 \%$ resultou numa remoção de $14,7 \%$ de cromo e 3,8\% de chumbo.

Steele e Pichtel (1998) avaliaram o uso de EDTA, ácido n-2acetamido-imino-di-acético, ácido piridina-2,6-dicarboxílico e ácido clorídrico como soluçôes de lavagem de solo contaminado, que continha $65.200 \mathrm{mg} / \mathrm{kg}$ de chumbo e $52 \mathrm{mg} / \mathrm{kg}$ de cádmio. O solo era submetido a três ciclos de extração de uma hora com cada um dos agentes de lixiviação. Os pesquisadores obtiveram remoção de $54 \%$ de $\mathrm{Pb}$ com ácido clorídrico. O teor de chumbo no solo tratado com o ácido não estava abaixo do limite estabelecido pela legislação $(1.000 \mathrm{mg} / \mathrm{kg})$.

Pichtel et al. (2001) avaliaram a eficiência de extração de chumbo com EDTA e soluções de ácido piridina2,6-dicarboxílico 0,0225 M e de ácido clorídrico $0,1 \mathrm{M}$ e $1 \mathrm{M}$, de um solo silto-argiloso, de sedimentos e de uma areia artificialmente contaminados com sulfato de chumbo, bem como de um solo contaminado de uma indústria de reciclagem de baterias. Os autores conseguiram uma eficiência de remoção de até $30 \%$ de chumbo no solo contaminado e de 30 a $51 \%$ nos solos artificialmente contaminados, utilizando solução de $\mathrm{HCl} 1 \mathrm{M}$.

\section{CONCLUSÕES}

A partir dos resultados obtidos no presente trabalho, conclui-se:

- A lixiviação do $\mathrm{Pb}$ com ácido sulfúrico não se mostrou eficiente, pois foi produzido sulfato de chumbo, cuja solubilidade em água é baixa. Por esta razão, a massa de chumbo do solo 
tratado com o ácido aumentou com o decréscimo de $\mathrm{pH}$;

- Obteve-se remoção de $\mathrm{Zn}$, através da lavagem do solo com ácido sulfúrico, de até $50 \%$, sendo o teor remanescente igual a $117 \mathrm{mg} / \mathrm{kg}$, valor abaixo do limite de prevenção determinado pelo órgão de controle ambiental do Estado de São Paulo, que indica que houve alteração das condições naturais do solo, porém a adoção de medidas corretivas não é necessária;

- O consumo de ácido sulfúrico concentrado por quilo de solo tratado foi de 12,4 g;

- O material contaminado apresentou teor de carbono de 0,4 a $0,8 \%$. Provavelmente, este teor refere-se ao material húmico, que apresenta refratabilidade à oxidação química. Desta forma, somente com dosagens de 40 e $50 \%$ (massa/massa) de peróxido de hidrogênio, foram obtidas remoçôes de 43 e $41 \%$ de carbono, respectivamente;

- A oxidação da suspensão de solo com peróxido de hidrogênio foi ineficaz na remoção de $\mathrm{Pb}$ e $\mathrm{Zn}$, devido à transferência da massa dos metais da fase sólida para os sólidos em suspensão da fase líquida. A quantidade da solução de peróxido de hidrogênio a $30 \%$ utilizada para tratamento do solo, conforme dosagens, esteve entre $151 \mathrm{gH}_{2} \mathrm{O}_{2} / \mathrm{kg}$ solo seco (dosagem $4,53 \%)$ e $1.666 \mathrm{~g} \mathrm{H}_{2} \mathrm{O}_{2} / \mathrm{kg}$ solo seco (dosagem 50\%);

- A reação altamente exotérmica desencadeada após a adição da solução de peróxido de hidrogênio à suspensão de solo produziu a grande liberação de vapores e pequena perda de massa, o que prejudicou a determinação da quantidade de massa dissolvida de $\mathrm{Pb}$ e Zn;

- A lixiviação dos metais do solo produzida pela solução de ácido clorídrico $0,1 \mathrm{M}$ reduziu os teores de $\mathrm{Pb}$ e $\mathrm{Zn}$ em 15 e $10 \%$, respectivamente, tendo sido consumido $196 \mathrm{~g}$ de $\mathrm{HCl}$ por quilo de solo tratado. Os teores remanescentes de chumbo e zinco, próximos de $806 \mathrm{mg} \mathrm{Pb/kg} \mathrm{e}$ $213 \mathrm{mg} \mathrm{Zn/kg}$, estão abaixo do limite estabelecido como valor de intervenção em áreas industriais, o que re-classifica a área de estudo como não contaminada;

- O solo contaminado da Regiáo dos Lagos de Santa Gertrudes pode ser remediado pela lavagem com os ácidos sulfúrico para a remoção de $\mathrm{Zn}$ e clorídrico para a remoção de $\mathrm{Pb}$ e $\mathrm{Zn}$.

\section{REFERÊNCIAS}

ALLOWAY, B.J. Heavy Metals in Soils. Second Edition, p. 3-57, 206-223, 284-305, Blackie Academic \& Professional, 1995

BEVILACQUA, J.E., LICHTIG, J. Caracterização Biogeoquímica de Sedimentos do Rio Tietê (Pirapora a Barra Bonita). Instituto de Química da Universidade de São Paulo, p. 1-24, 2004

BOURG, A.C.M. Speciation of Heavy Metals in Soils and Groundwater and Implications for Their Natural and Provoked Mobility. In: SALOMONS, W.; FÖRSTNER, U.; MADER, P. (Eds.). Heavy Metals Problems and Solutions, p. 19-31, SpringerVerlag Berlin Heidelberg, 1995.

BRASIL. ASSOCIAC̄̃̃O BRASILEIRA DE NORMAS TÉCNICAS (ABNT). Solo-Análise Granulométrica - NBR 7181, 1984.

MINISTÉRIO DA SAÚDE. Secretaria de Vigilância em Saúde. Vigisolo: identificação de populaçôes sob risco de exposição e priorização de áreas com populaçóes expostas a solo contaminado. Disponível em: <http://portal.saude.gov.br/por$\mathrm{tal} /$ svs/visualizar_texto.cfm? idtxt $=23900>$. Acesso em: 30/07/06.

BROOKINS, D. G. Eh-pH Diagrams for Geochemistry, p. 42-45, 54-55, Springer-Verlag Berlin Heidelberg, 1988.

CANADÁ. The National Contaminated Sites Remediation Program. Development and Demostration of Site Remediation Technology Program. Evaluation of Soil Washing andBioslurry Reactor Treatments for PCB-Heavy Metal Contaminated Soils, Washburn\&Gillis Associates Ltd. Project Summary, 1993. Disponível em http://www.qc.ec.gc.ca/dpe/Publication/ Detalc/14_e.htm. Acesso em 01/06/2006.

CETESB - COMPANHIA DE TECNOLOGIA EM SANEAMENTO AMBIENTAL. Áreas contaminadas no Estado de São Paulo. 2005. Disponível em: <http://www.cetesb.sp.gov. br/Solo/areas_contaminadas/relacao_areas.asp >. Acesso em: 14/07/06.

Di PALMA, L. et al. Recovery of EDTA and Metal Precipitation from Soil Flushing Solutions, Journal of Hazardous Materials, B(103), p. $153-168,2003$.

EEA (EUROPEAN ENVIRONMENT AGENCY). Progress in management of contaminated sites (CSI 015) - Assessment DRAFT created Jul 2006. Disponível em http://themes.eea.europa. eu/IMS/ISpecs/ISpecification20041007131746/ IAssessment $1152619898983 /$ view content. Acesso em 17/03/2006.

EVANGELOU, V.P. Environmental Soil and Water Chemistry: Principles and Applications, p. 564, Willey, New York, 1998.

JENSEN, P.E., OTTOSEN, L.M., PEDERSEN, N.J. Speciation of $\mathrm{Pb}$ in Industrially Polluted Soils. Water, Air and Soil Pollution, v. 170, p. 359-382, 2006.

KERSTEN, M., FÖRSTNER, U. Speciation of Trace Elements in Sediments. In: BATLEY, G.E. (Ed.). Trace Element Speciation: Analytical Methods and Problems, p. 245-317, CRC Press, Boca Raton, 1990.

NOGAMI, J.S. Pavimentação de Baixo Custo com Solos Lateríticos, p. 5-41, Vilibor, São Paulo, 1995.
NYER, E.K. et al. In Situ Treatment Technology, p. 329, CRC Lewis Publishers, Boca Raton, 1996.

PICHTEL, J., PICHTEL, T.M. Comparison of Solvents for Ex situ Removal of Chromium and Lead from Contaminated Soil. Environmental Engineering Science, v. 14, n. 2, p. 97-104, 1997.

PICHTEL, J et al. Lead Extration from Soils as Affected by Lead Chemical and Mineral Forms. Environmental Engineering Science, v. 18, n. 2, p. $91-98,2001$.

REED, B.E., CARRIERE, P.C., MOORE, R. Flushing of a $\mathrm{Pb}(\mathrm{II})$ Contaminated Soil Using $\mathrm{HCl}$, EDTA, and $\mathrm{CaCl}$. Journal of Environmental Engineering, American Society Civil Engineers, v. 122 , n. 1, p. 48-50, 1996.

RULKENS, W.H., GROTENHUIS, J.T.C., TICHÝ, R. Methods for Cleaning Contaminated Soils and Sediments. In: SALOMONS, W., FÖRSTNER, U., MADER, P. (Eds.). Heavy Metals Problems and Solutions, p. 165-186, Springer-Verlag Berlin Heidelberg, New York, 1995.

SILVA, A.L.B. Caracterização Ambientale Estudo do Comportamento do Chumbo, Zinco e Boro em Área Degradada por Indústrias Cerâmicas - Região dos Lagos de Santa Gertrudes, SP, 229p, Dissertação (Mestrado), Instituto de Geociências, Universidade de São Paulo, 2001.

STEELE, M.C., PICHTEL, J. Ex-Situ Remediation of a Metal-Contaminated Superfund Soil Using Selective Extractants, Journal of Environmental Engineering, American Society Civil Engineers, v. 124, n. 7, p. $639-45,1998$.

USEPA(UNITED STATES ENVIRONMENTAL PROTECTION AGENCY). Acid Extraction Treatment System for Treatment of Metal Contaminated Soils. Cincinnati, Ohio: EPA. EPA/540/R-94/513, 1994.

Acid Digestion of Sediments, Sludges and Soils - Método 3050B, 1996a.

Inorganics by ICP - Atomic Emission Spectroscopy - Método 6010B, 1996b.

Cleaning Up the Nation's Waste Sites: Markets and Technology Trends. Washington: EPA, 2004.

WASAY, S.A., BARRINGTON, S.F., TOKUNAGA, S. Using Aspergillus niger to Bioremediate Soils Contaminated by Heavy Metals, Bioremediation Journal, v. 2(3), p. 183-190, 1998.

Endereço para correspondência:

Luciana Pena de Oliveira

Avenida Conselheiro Rodrigues

Alves, 3 I 5 - Apt $^{\circ}$ I 2 - Vila

Mariana

040 I 4-0 I 0 São Paulo -SP - Brasil

Tel.: (I I) 9972-4676

E-mail: lupena@gmail.com 